\title{
DETERMINATION OF MEAT PRODUCTIVITY OF «BLAGOVARSKY» CROSS DUCKS
}

\begin{abstract}
Feeding is the main condition for high productivity of ducks. It provides the need for metabolizable energy and nutrients according to modern standards. Ducks have an increased need for arginine, histidine, tryptophan, glycine, threonine and valine, therefore much attention is paid to the amino acid composition of feed in normalizing feeding. It is also important to consider the level of digestibility of the proposed feed. The feed nutrients digestibility depends on various factors and therefore varies considerably.

Optimal ratios of carbohydrates, proteins, fats, etc. in the diet contribute to a high level of digestibility. The level of fiber and protein significantly affects the digestibility of nutrients in the feed. Increasing the amount of fiber (especially rich in lignin) reduces the digestibility of fiber and other nutrients. Essential influence on the nutrients digestibility is caused by the available protein content in the feed and its ratio with carbohydrates and fats. In this regard, the protein ratio of feed is determined. The protein ratio shows how many parts of digested nitrogen-free nutrients account for each part of digested protein.

In addition, the feed preparation for feeding has a positive effect on their digestibility (moisturizing, enriching, grinding, steaming and others). The nutrients digestibility is also affected by different levels of macro-, micronutrients and vitamins in the feed. Increasing the feed nutrients digestibility is an important factor in reducing their costs, the cost of livestock products and improving the economic efficiency of the industry. Young ducks are characterized by precocity and high growth rate. At the age of 7 weeks, the live weight of hybrid young ducks is $3.2-3.4 \mathrm{~kg}$, and during this period the initial weight increases more than 60 times at a feed consumption per $1 \mathrm{~kg}$ gain of $2.8-3.0 \mathrm{~kg}$ and average daily gain $64-68 \mathrm{~g}$.

The positive effect of the use of the developed vitamin-mineral premix in the compound feed composition on the meat productivity of "Blagovarsky" cross ducks has been determined. It was determined that from the third week of growing the live weight of young ducks of the experimental group was higher of analogues of the control group for 3,2\%. Analysis the main indicators of young ducks productivity showed that the bird of the experimental group exceeded analogues in the following periods of growth: 0 - 7 days, 15 - 21 days, 29 - 35 days, 36 - 42 days, 43 - 49 days.

Survival rate of young ducks was at a high level in the range of $97-99.5 \%$ for the entire period of growing in both groups. Starting from the 4th week of growing, the survival rate decreased slightly in the control group and amounted to 99.1, which is $0,2 \%$ less than in the experimental group. The increased concentration of premix in the compound feed for the young ducks of the experimental group help to improve their slaughter qualities in comparison with the control group.
\end{abstract}

Key words: young ducks, poultry, meat productivity, metabolizable energy, ontogenesis, live weight, safety.

\section{Introduction}

The ability of poultry to provide high-quality food to the population is one of the main biological features. It is known that one egg satisfies a person's need for vitamin A by $15-17 \%, \mathrm{~B}_{2}-10-13 \%, \mathrm{~B}_{12}-55-$ $100 \%$, D - $13-40 \%$. Egg white is almost completely digested by humans.

Duck breeding is an important source of poultry meat especially in intensive production. High efficiency of their breeding is based on the use of valuable biological features of birds of this species. The female bird has a well-developed ovary. It concentrates a significant amount of nutrients (yolk) with the development of the follicle. Unlike mammals the oviduct in poultry not only acts as a "tube" but also produces nutrients (egg white) and forms the egg shell (soft - subshell and hard - shell). In addition, it performs the function of long-term storage of sperm and is a fusion site of male and female gametes.

Young ducks are characterized by precocity and high growth rate. At the age of 7 weeks the live weight of hybrid young ducks is $3.2-3.4 \mathrm{~kg}$, and during this peri- od the initial weight increases more than 60 times at a feed consumption per $1 \mathrm{~kg}$ gain of $2.8-3.0 \mathrm{~kg}$ and aver age daily gain $64-68 \mathrm{~g}$. [1, 2].

Ducks for meat can be breed in any climatic zone of the country using year-round or seasonal growing. Adult and young ducks adapt well to modern industrial production conditions [3].

\section{Purpose and objectives of the analysis}

The purpose of the work was to determine the effect of the use of the developed vitamin-mineral premix in the compound feed composition on the meat productivity of "Blagovarsky" cross ducks.

\section{Materials and methods}

Researches on establishment of influence on growth and development of young ducks of the developed vitamin-mineral premix in the compound feed composition carried out in the farm property of IE "Manko A.G." and the Department of Genetics, Breeding and Feeding of Farm Animals of the Odessa State Agrarian University.  
"Blagovarsky" cross ducks were selected for the study. The study conducted by the method of groups analogues (table 1). 100 heads of daily ducklings were selected. 2 groups were formed from them - control and experimental, 50 heads ( 25 males and 25 females) in each, according to the principle of analogues. Age, sex and live weight were taken into account when selecting analogues.

Therapeutic and preventive treatment of the premises was carried out before placement the ducklings (table. 2).

The bird kept on the floor with free access to feed and water. All poultry received complete feed balanced in nutrients and biologically active substances in accordance with the direction of productivity and growing period. Vitamin-mineral premix was added at the rate of $1.4 \%$ per 1 ton of feed to the diet of ducklings of the experimental group $[4,5]$.

\section{Results and its discussion}

Nutrients digestibility is the initial stage of interaction of feed with the body and therefore does not give a complete picture of the impact of feed nutrients on the animal (its condition, reproductive capacity, productivity). It is impossible to draw a clear line between organic and mineral elements, this division is conditional. Metabolism in the body is the general process and mineral metabolism is one of its aspects. An example is the phosphorus metabolism, which connects the body's processes of protein, carbohydrate, lipid, mineral and energy metabolism. This applies to sulfur, magnesium, iron, zinc and other elements to some extent. Minerals are not a source of energy, but in the animal's body perform various functions.

As a result of the conducted researches the growth rates of ducks and average weekly feed consumption per 1 head, norms of nutrient content in complete feed are established (table 3). Ducks are almost omnivorous. They can easily consume and digest raw materials of plant and animal origin.

Poultry is second only to fish in terms of feed conversion. Thus, broilers consume $2-2.5 \mathrm{~kg}$ of concentrates per $1 \mathrm{~kg}$ of live weight gain, while pigs $-4-5 \mathrm{~kg}$. The production of food protein from eggs and poultry is much more economical than from other livestock industries.

The table shows that the ducklings received a complete feed that met physiological needs in different periods of ontogenesis. Data of the ducklings growth rate are shown in table 4.

Intense metabolic processes flows inside the poultry organism. Thus, $33 \mathrm{~g}$ of feed units of complete feed are required per $1 \mathrm{~kg}$ of chicken live weight, which is in 3.3 times higher than for cattle. Birds have a constant body temperature (in most species is in the range of $+41-$ $42{ }^{\circ} \mathrm{C}$ ). Poultry blood mass is $8-12 \%$ of body weight, no blood groups. Blood pressure is between 140 and 170 $\mathrm{mm} \mathrm{Hg}$ [4].

Table 1 - Scheme of scientific experience

\begin{tabular}{|c|c|c|c|}
\hline Groups of birds & $\begin{array}{l}\text { Number of birds in } \\
\text { the group, heads }\end{array}$ & Method of feeding & $\begin{array}{l}\text { Duration of the } \\
\text { experiment, days }\end{array}$ \\
\hline I- control & 50 & $\mathrm{CF}^{*}$ & 56 \\
\hline II- experimental & 50 & $\mathrm{CF}^{*}+$ premix $(14 \mathrm{~kg} / \mathrm{t}$ of compound feed $)$ & 56 \\
\hline
\end{tabular}

Table 2 - Therapeutic and preventive treatment of premises

\begin{tabular}{||c||c||c||c||}
\hline \hline Period & Preparation & Treatment, dose & Action \\
\hline \hline $\begin{array}{c}\text { Pre- } \\
\text { placement }\end{array}$ & Virkon $-\mathrm{S}$ & $2 \%-$ aerosol solution & Prevention of bacteriological and viral diseases \\
\hline \hline $1-4$ day & Lovit & Drinking $0.25-0,5 \mathrm{ml} / 1$ & Anti-stress treatment \\
\hline \hline $5-9$ day & Enroxil $10 \%$ & Drinking $0.5-1 \mathrm{ml} / 1$ & Prevention of respiratory and gastric diseases \\
\hline \hline $10-14$ day & Lovit & Drinking $0.25-0,5 \mathrm{ml} / 1$ & Increasing the body's resistance and stimulating growth \\
\hline
\end{tabular}

Table 3 - Norms of nutrient content in complete feed

\begin{tabular}{|c|c|c|c|c|c|c|}
\hline Complete feed & $\begin{array}{l}\text { Metabolizable energy } \\
\text { of feed, } \mathrm{kcal} / 100 \mathrm{~g}\end{array}$ & $\begin{array}{l}\text { Crude } \\
\text { protein, } \%\end{array}$ & $\begin{array}{l}\text { Crude } \\
\text { fiber, } \%\end{array}$ & $\mathrm{Ca}, \%$ & $\mathrm{P}, \%$ & $\mathrm{Na}, \%$ \\
\hline for ducks aged $1-20$ days & 280 & 20 & 5 & 1.2 & 0.8 & 0.4 \\
\hline for ducks aged $21-56$ days & 290 & 18 & 6 & 1.2 & 0.8 & 0.4 \\
\hline
\end{tabular}

Table 4-Growth rate of "Blagovarsky" cross ducks live weight, $g(M \pm m, n=100)$

\begin{tabular}{|c|c|c|c|c|c|c|c|c|}
\hline \multirow{2}{*}{$\begin{array}{c}\text { Groups of } \\
\text { ducks }\end{array}$} & \multicolumn{8}{|c|}{ "Age, weeks } \\
\hline & 0 & 1 & 2 & 3 & 4 & 5 & 6 & 7 \\
\hline Control & $\begin{array}{c}51.47 \\
\pm \\
0.46\end{array}$ & $\begin{array}{c}207.44 \\
\pm \\
3.07\end{array}$ & $\begin{array}{c}645.14 \\
\pm \\
7.72\end{array}$ & $\begin{array}{c}1249.53 \\
\pm \\
16.44\end{array}$ & $\begin{array}{c}1871.78 \\
\pm \\
26.36\end{array}$ & $\begin{array}{c}2422.65 \\
\pm \\
23.12\end{array}$ & $\begin{array}{c}3014.70 \\
\pm \\
25.77^{* *}\end{array}$ & $\begin{array}{c}3423.15 \\
\pm \\
24.82^{* *}\end{array}$ \\
\hline Experimental & $\begin{array}{c}51.72 \\
\pm \\
0.60\end{array}$ & $\begin{array}{c}217.1 \\
\pm \\
0.51\end{array}$ & $\begin{array}{c}649.62 \\
\pm \\
3.2\end{array}$ & $\begin{array}{c}1385.81 \\
\pm \\
4.39\end{array}$ & $\begin{array}{c}1927.91 \\
\pm \\
7.95^{* *}\end{array}$ & $\begin{array}{c}2497.76 \\
\pm \\
21.66\end{array}$ & $\begin{array}{c}3117.19 \\
\pm \\
27.78\end{array}$ & $\begin{array}{c}3532.69 \\
\pm \\
26.08\end{array}$ \\
\hline
\end{tabular}

Note: ** - $\mathrm{P}<0,01$ compared with the control group. 
Table 5 - Live weight gains of “Blagovarsky" cross ducks

\begin{tabular}{|c||c|c||c|c|c|c|}
\hline \multirow{2}{*}{$\begin{array}{c}\text { Age, } \\
\text { days }\end{array}$} & \multicolumn{2}{|c|}{ Absolute gain, $\mathrm{g}$} & \multicolumn{2}{c|}{ Average daily gain, g } & \multicolumn{2}{c|}{ Relative gain, \% } \\
\cline { 2 - 7 } & Control & Experimental & Control & Experimental & Control & Experimental \\
\hline \hline $0-7$ & 155.97 & 165.38 & 22.28 & 23.62 & 120.48 & 123.04 \\
\hline \hline $8-14$ & 437.7 & 432.52 & 65.52 & 61.79 & 102.68 & 99.8 \\
\hline \hline $15-21$ & 604.39 & 736.19 & 86.34 & 105.17 & 63.8 & 72.34 \\
\hline \hline $22-28$ & 622.25 & 539.1 & 88.89 & 77.01 & 39.87 & 32.72 \\
\hline \hline $29-35$ & 550.87 & 569.85 & 78.69 & 81.41 & 25.65 & 25.75 \\
\hline \hline $36-42$ & 592.05 & 619.43 & 84.57 & 88.49 & 21.78 & 22.06 \\
\hline \hline $43-49$ & 408.45 & 415.50 & 58.35 & 59.36 & 12.69 & 12.49 \\
\hline
\end{tabular}

Analyzing the dynamics of changes in the live weight of "Blagovarsky" cross ducks with different methods of feeding, it is determined the differences between the birds of the experimental and control groups, and certain deviations from the normative indicators of live weight. It should be noted that in the first three weeks the live weight of ducklings did not differ. Starting from the third week of growing the live weight of young ducks of the experimental group was higher of analogues of the control group for $3.2 \%$.

Live weight gains are the main indicator of meat poultry productivity, so we calculated the absolute, relative and average daily live weight gains of ducks of the control and experimental groups (Table 5).

Analysis the table data showed that the rates of absolute live weight gain of young ducks were higher in the experimental group in the following periods of ontogenesis: $0-7$ days, $15-21$ days, $29-35$ days, $36-42$ days, $43-49$ days. The largest difference in the average daily live weight gain of ducklings between the experimental and control groups was observed at the 3rd week of growth and amounted to $131.8 \mathrm{~g}$. The largest relative live weight gains of ducklings were at the beginning of the rearing period, in the first two weeks. That is natural for all farm animals.

The survival of young ducks is an indirect indicator of meat productivity. The quality and yield of meat products depend on it (Table 6).

Analysis of the table data shows that the survival rate of young ducks was at a high level in the range of 97-99.5\% for the entire period of growing in both groups. Starting from the 4th week of growing, the survival rate decreased slightly in the control group and amounted to 99.1 , which is $0.2 \%$ less than in the experimental group.

Table 6-Survival rate of young ducks for the entire period of growing, \%

\begin{tabular}{|c||c||c||}
\hline \multirow{2}{*}{ Age, weeks } & \multicolumn{2}{|c|}{ Groups } \\
\cline { 2 - 3 } & Control & Experimental \\
\hline \hline 1 & 99.6 & 99.5 \\
\hline \hline 2 & 99.3 & 99.3 \\
\hline \hline 4 & 99.1 & 99.3 \\
\hline \hline 5 & 98.9 & 99.0 \\
\hline \hline 6 & 97.4 & 98.7 \\
\hline \hline 7 & 97.5 & 98.5 \\
\hline \hline
\end{tabular}

The slaughter qualities of young ducks of the control and experimental groups were determined at the last stage of the study (table 7).

Table 7 - The slaughter qualities of young ducks, $g$

\begin{tabular}{||l||c|c|}
\hline \multicolumn{1}{|c||}{ Indicator } & \multicolumn{2}{c|}{ Groups } \\
\cline { 2 - 3 } & Control & Experimental \\
\hline \hline $\begin{array}{l}\text { Pre-slaughter live } \\
\text { weight }\end{array}$ & 3420 & 3530 \\
\hline \hline $\begin{array}{l}\text { Carcass weight: } \\
\text { not gutted }\end{array}$ & 3078 & 3141.7 \\
\hline \hline semi-gutted & 28856.6 & 2984.61 \\
\hline \hline gutted & $2371.75 \pm 8.66$ & $2444.11 \pm 6.86$ \\
\hline \hline $\begin{array}{l}\text { Mass of eatable } \\
\text { parts: } \\
\text { pectoral muscles }\end{array}$ & $333.89 \pm 8.91$ & $351.1 \pm 6.42$ \\
\hline \hline leg muscles & $315.00 \pm 5.22$ & $315.87 \pm 5.26$ \\
\hline \hline $\begin{array}{l}\text { skin with } \\
\text { subcutaneous fat }\end{array}$ & $555.21 \pm 9.11$ & $528.66 \pm 9.78$ \\
\hline \hline internal fat & $27.87 \pm 1.01$ & $29.12 \pm 1.20$ \\
\hline \hline liver & $128.25 \pm 5.01$ & $143.31 \pm 7.01$ \\
\hline \hline lungs & $31.07 \pm 1.40$ & $33.82 \pm 1.11$ \\
\hline \hline kidneys & $18.99 \pm 1.29$ & $21.40 \pm 1.54$ \\
\hline \hline muscular stomach & $127.75 \pm 6.87$ & $115.25 \pm 5.21$ \\
\hline \hline heart & $21.09 \pm 1.12$ & $25.01 \pm 2.11$ \\
\hline \hline
\end{tabular}

It is seen from the given data that the increased concentration of premix in the compound feed for the young ducks of the experimental group help to improve their slaughter qualities in comparison with the control group.

\section{Conclusions}

As a result of the conducted researches the positive effect of the use of the developed vitamin-mineral premix in the compound feed composition on the meat productivity of "Blagovarsky" cross ducks has been determined. It was determined that the growth rate of ducklings live weight of the experimental group was higher of analogues of the control group. Survival rate of young ducks was at a high level in the range of $97-99.5 \%$ for the entire period of growing in both groups. Slaughter qualities of young ducks were significantly higher at the experimental group than the control. 


\section{REFERENCES}

1. Balanchuk I. M. Zabiyni yakosti kachenyat za riznikh rivniv obminnoyi enerhiyi u kombikormakh / I. M. Balanchuk // Suchasne ptakhivnitstvo. - 2012. - T. 8, vip. 117. - S. 24-27.

2. Patryeva L. S. Dinamika zhivoyi masi ta yakist ' m"yasa kachenyat krosu «Temp» za riznikh sistem utrimannya / L. S. Patryeva, T. V. Shevchenko // Institut biolohiyi tvarin NAAN. Odesa, 2020. - URL: https://inenbiol.com/ntb/ntb/pdf/2/14/.pdf. (data zvernennya: 23.08.2020).

3. Spirodonov I. P. Kormlenie sel skokhozyaystvennoy ptitsy: monohrafiya / I. P. Spirodonov, A. B. Mal'tsev, V. M. Davydov - Omsk: Omsk, 2002. - 696 s.

4. Bakanov V. A. Kormlenie sel’s kokhozyaystvennykh zhivotnykh: monohrafiya / V. A. Bakanov, V. K. Mel'kin Moskva: Ahropromizdat, 1989. - 511 s.

5. Svezhentsov A. I. Korma i kormlenie sel skokhozyaystvennoy ptitsy: monohrafiya / A. I. Svezhentsov, R. M. Rudzik, I. A. Ehorov - Dnepropetrovsk: ART- PRESS, 2006. - $384 \mathrm{~s}$.

Д.Л. Терземан, аспірант, https://orcid.org/0000-0001-9387-0555

E.mail: dimaterzeman@ukr.net

О. Й. Карунський, д-р с.-г. наук, професор

https://orcid.org/ 0000-0001-8180-1587, Researcher ID: B-3788-2016

Одеський державний аграрний університет, вул. Пантелеймонівська, 13, м. Одеса, 65039, Украӥна

\section{ВИЗНАЧЕННЯ МЯСНӦ̈ ПРОДУКТИВНОСТІ КАЧОК КРОСУ «БЛАГОВАРСЬКИЙ»}

\section{Анотація}

Основною умовою високої продуктивності качок є годівля, яка забезпечує потребу в обмінній енергії $i$ поживних речовинах згідно сучасних норм. При нормуванні годівлі велика увага приділяється амінокислотному складу кормів через те, щчо качки мають підвищену потребу в аргініні, гістидині, триптофані, гліцині, треоніні та валіні. Також важливо враховувати рівень перетравності запропонованого комбікорму. Перетравність поживних речовин кормів залежить від різноманітних факторів, а тому значно варіює.

Оптимальні співвідношення вуглеводів, білків, жирів та ін. у раціоні сприяють високому рівню перетравності. На перетравність поживних речовин значно впливає рівень клітковини та протеїну у кормі (раціоні). Збільшення кількості клітковини (особливо багатої лігніном) знижує перетравність самої клітковини та інших поживних речовин. Суттєвий вплив на перетравність поживних речовин спричиняє вміст у кормі доступного тваринам протеїну, його співвідношення з безазотистими речовинами. У зв'язку з ичим визначають протеїнове відношення корму (раціону). Протеїнове відношення показує, скільки частин перетравлених безазотистих поживних речовин припадає на кожну частину перетравленого протеїну.

Поряд із викладеними факторами на перетравність кормів (раціонів) позитивно впливає їх підготовка до згодовування (зволоження, здобрення, подрібнення, пропарювання та інші). На перетравність поживних речовин також впливають різні рівні у кормі (раціоні) макро-, мікроелементів та вітамінів.

Підвищення перетравності поживних речовин кормів є важливим фактором зниження їх витрат, зменшення собівартості продуктів тваринництва і поліпшення економічної ефективності галузі.

Молодняк качок характеризується скороспілістю і високою інтенсивністю росту. В 7-тижневому віці жива маса гібридних каченят становить 3,2 - 3,4 к2, а початкова маса за цей період зростає більш як у 60 разів за витрати корму на 1 кг приросту 2,8 - 3,0 кг і середньодобових приростів $64-68$ г.

Визначено позитивний вплив використання у годівлі розробленого вітамінно-мінерального преміксу у складі повнораціонного комбікорму на м'ясну продуктивність качок кросу «Благоварський». Встановлено, що каченята дослідної групи починаючи з третього тижня вирощування переважали за живою масою аналогів контрольної групи на 3,2. Аналізуючи основні показники продуктивності каченят, встановили, щзо птиця дослідної групи переважала аналогів у наступні періоди вирощування : 0 - 7 день, 15 - 21 день, 29 - 35 день, 36 - 42 день, $43-49$ день.

Збереженість каченят за весь період вирощування у обох групах була на високому рівні в межах 97 99,5\%. Починаючи з 4 - го тижня вирощування показник збереженості дещз знизився у контрольній групі $i$ становив 99,1, щуо на 0,2 \% менше порівняно з дослідною групою. Підвищена концентрація преміксу у складі повнорачіонного комбікорму, що отримували каченята дослідної групи, сприяла покращенню їх забійних якостей у порівнянні з контрольною групою.

Ключові слова: каченята, м'ясна птиия, м'ясна продуктивність, обмінна енергія, онтогенез, жива маса, збереженість.

\section{ЛIТЕРАТУРА}

1. Баланчук I. М. Забійні якості каченят за різних рівнів обмінної енергії у комбікормах / I. М. Баланчук // Сучасне птахівництво. - 2012. - Т. 8, вип. 117. - С. 24-27.

2. Патрєва Л. С. Динаміка живої маси та якість м'яса каченят кросу «Темп» за різних систем утримання / Л. С. Патрєва, Т. В. Шевченко // Інститут біології тварин НАAН. - Одеса, 2020. - URL: https://inenbiol.com/ntb/ntb/pdf/2/14/.pdf. (дата звернення: 23.08.2020). 
3. Спиродонов И. П. Кормление сельскохозяйственной птицы: монография / И. П. Спиродонов, А. Б. Мальцев, В. М. Давыдов - Омск: Омск, 2002. - 696 с.

4. Баканов В. А. Кормление сельськохозяйственных животных: монографія / В. А. Баканов, В. К. Мелькин Москва: Агропромиздат, 1989. - 511 с.

5. Свежениов А. И. Корма и кормление сельскохозяйственной птицы: монография / А. И. Свеженцов, Р. М. Рудзик, И. А. Егоров - Днепропетровск: АРТ- ПРЕСС, 2006. - 384 с.

Cite as Vancouver Citation Style

Terzeman D., Karunskyi O. Determination of meat productivity of «Blagovarsky» cross ducks. Grain Products and Mixed Fodder's, 2020; 20 (4, 80): 29-33. DOI https://doi.org/

Cite as State Standard of Ukraine 8302:2015

Determination of meat productivity of «Blagovarsky» cross ducks / Terzeman D. et al. // Grain Products and Mixed Fodder's. 2020. Vol. 20, Issue 4 (80). P. 29-33. DOI https://doi.org/

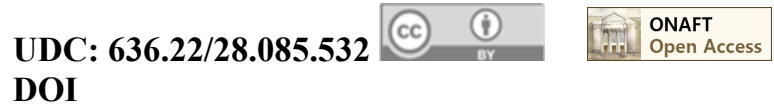

O. Karunskyi, Doctor of Agricultural Sciences, Professor https://orcid.org/ 0000-0001-8180-1587, Researcher ID: B-3788-2016 E.mail: tatianareznik11@gmail.com G.I. Kotets, PhD of Agricultural Sciences M. M. Madani, PhD of Technical Sciences, Associate Professor Odessa State Agrarian University, 13, Panteleimonivska Str., Odessa, 65000, Ukraine

\section{CHEMICAL COMPOSITION AND NUTRITIONAL VALUE OF THE NEW CITRUS POMACE FEED ADDITIVE}

The materials of the article present data on research on the chemical, mineral-vitamin composition and nutritional value of a new feed additive from citrus pomace. The article presents the results of research on the technological line of granulation of citrus waste, established the optimal composition for granulation of citrus feed additives: sunflower meal - 20\%, molasses - 5\% and $75 \%$ of citrus fruits.

Their chemical composition was studied, the gross content of proteins, fats, assimilated carbohydrates, including simple sugars, was determined, and the efficiency of use in the diets of farm animals was determined. The positive influence of citrus waste granulation technology has been established, which allows to obtain high-quality granules. Chemical analysis of citrus granules showed that $100 \mathrm{~g}$ contains: protein $-6.15 \mathrm{~g}$, fat $-0.99 \mathrm{~g}$, carbohydrates - $21.8 \mathrm{~g}$, of which simple sugars $14 \mathrm{~g}$, the energy value of this feed additive - Kcal (kJ) - 120.7 (505.7).

The possibility of preparation of feed additives in the form of granules is revealed, which allows to avoid selfsorting of components and overdose of microelements and to improve the consumption of feed ingredients. The ability to prepare feed additives in the form of granules avoids self-sorting of components and overdose of micronutrients and improve the consumption of feed ingredients. The results of zootechnical researches, structure and nutritional value of average daily rations with use of citrus pomace are resulted.

It was found that the introduction into the diet of dairy cows feed additives from citrus pomace during stable lactation increases the average daily expectations by $1.8 \mathrm{~kg}$ or $15.5 \%$, feed costs for milk production containing 4 fat were 0.97-0, 98 feed units. When using a feed additive from citrus pomace, the nutritional value of the diet is improved due to the ratio of sugar - protein (0.62: 1 vs. 0.8: 1.2).

Key words: granules, proteins, fats, carbohydrates, energy value.

\section{Introduction}

Domestic and world experience of increasing the production of livestock products and reducing their cost shows that in recent years an increase in animal productivity by $65 \%$ has been achieved by improving their feeding system and advanced housing technologies. It follows that the organization of rational full-fledged feeding of farm animals is one of the main conditions for further increase of their productivity $[3,5,9]$.
As the knowledge of the animal's need for nutrients increases, so does the concept of the level of a complete diet. Detailed norms and rations of feeding farm animals reflect modern knowledge, on the basis of which a scientifically sound and well-founded feeding system has been developed [1].

Full supply of animals with all nutrients, minerals and biologically active substances, determines not 